\title{
Model of Relationships between Land Surface Temperature and Urban Built-Up Areas in Mueang Buriram District, Thailand
}

\author{
Tanutdech Rotjanakusol, Teerawong Laosuwan* \\ Department of Physics, Faculty of Science, Mahasarakham University, Maha Sarakham, Thailand
}

Received: 30 August 2019

Accepted: 7 January 2020

\begin{abstract}
At present, the climate has constantly been changing rapidly, especially global average temperatures that have increased dramatically. Just a few degrees of rising temperature can cause many natural disasters. The purposes of this research is to determine the relationship between land surface temperature and urban built-up areas by applying Landsat-8 satellite data in 2018 in Mueang Buriram district, Buriram province, Thailand. The research was conducted by estimating land surface temperature using a split-window algorithm mutually with an analysis of land use and supervised classification methods. The study results of land surface temperature in each district indicated that Nai Mueang sub-district had the highest average land surface temperature at $33.27^{\circ} \mathrm{C}$ and that Lak khet sub-district had the lowest average land surface temperature at $28.79^{\circ} \mathrm{C}$. The study results of land use in 3 main areas indicated as follows: 1) vegetation areas had an area of $703.40 \mathrm{~km}^{2}$, representing $084.41 \%$ 2) urban built-up areas had an area of $118.28 \mathrm{~km}^{2}$, representing $14.19 \%$ and 3) and water areas had an area of $11.61 \mathrm{~km}^{2}$, representing $1.40 \%$. The study results of the relationship between land surface temperature and urban built-up areas indicated an excellent level of relationship and the value of correlation $r$ at 0.9719 . In addition, land surface temperature was forecasted in advance, when urban built-up areas had increased to $100 \%$. And the results were found that Mueang Buriram district had an increasing land surface temperature of approximately at $35.11^{\circ} \mathrm{C}$.
\end{abstract}

Keywords: land surface temperature, urban built-up areas, split-window algorithm, remote sensing

\section{Introduction}

The $4^{\text {th }}$ World Weather Report by the IPCC states that global warming has become more apparent. The climate forecasting model concluded by IPCC

*e-mail: teerawong@msu.ac.th

indicates that the global average temperature at the Earth's surface will increase by $1.1-6.4^{\circ} \mathrm{C}$ during the $21^{\text {st }}$ century (2001-2100). Such values were derived from simulating different situations of greenhouse gas emissions in the future, including simulating various forms of climate sensitivity. Although the majority of all studies were focused in the specified period until 2100 , temperatures and sea levels have continually been rising for many millennia, although the level of 
greenhouse gases has already become stable, slowly approaching an equilibrium state of temperatures and sea levels resulting from of the extremely high level of heat capacity of ocean water [1].

For Thailand, especially in the northeastern region, it was found that the average annual temperature in 2018 was $27.2^{\circ} \mathrm{C}$ (the normal temperature was $26.8^{\circ} \mathrm{C}$ ), which was $0.4^{\circ} \mathrm{C}$ higher than the normal temperature. Northeastern Thailand has a savanna-like climate with alternate tropical and dry climates. The region also has moderate rainfall and consists of three seasons: summer (between February and May), rainy (between May and October) and winter (between October and February). Moreover, many areas in Thailand had higher average monthly temperatures than the normal temperatures of every month. Especially in November and December we found that the average monthly temperatures were higher than normal temperatures at $2.1^{\circ} \mathrm{C}$ and $1.9^{\circ} \mathrm{C}$, respectively [2]. The current urban areas had been developed from economic growth and also resulted in the change in land uses [3]. Various areas were developed and improved to become economic areas. The original areas, which were formerly vegetation areas, were replaced by basic public utility systems such as buildings, roads and other basic infrastructures. The original areas, which are vegetation, soil and water sources, had been transformed to surfaces with concrete elements and asphalt that resulted in the increase in solar heat absorption on the surfaces of such those areas [4-6].

Buriram province is one of the provinces of Thailand that was the target of implementing strategies and economic development. The significant potentials of this province are tourist attractions that are the center of Khmer civilization. It consists of a famous and standardized football stadium, a world-class motorsport racecar track and real estate investments (as can be seen from the increase in the construction of department stores, condominiums and residences with continued expansion of community areas). The study of the relationship between such areas and surface temperatures is an indication of the awareness of temperature changes in Buriram Province, while more communities and buildings are created increasingly and usefully for planning and developing the whole city plan in the future [7]. Briefly, the land surface temperature study is a study of the surface temperature of the world [8-10]. Nowadays, remote sensing technology with the use of satellite data can be applied to estimate land surface temperature effectively [11-13].

At any rate, recording satellite data will show the reflections of electromagnetic radiations, which may be building roofs, treetops, ice, snow, etc. Therefore, land surface temperature is different from air temperature [14]. Mostly, land surface temperature will be utilized in various fields, such as studies of global climate change from the increases of temperature, studies of climate patterns by examining the increase of greenhouse gases in the atmosphere affecting ground temperatures [15], and studies of the increase in surface temperatures affecting glaciers, ice sheets and vegetation in the global ecosystem [16, 17]. Many current research studies have given precedence to land surface temperature and

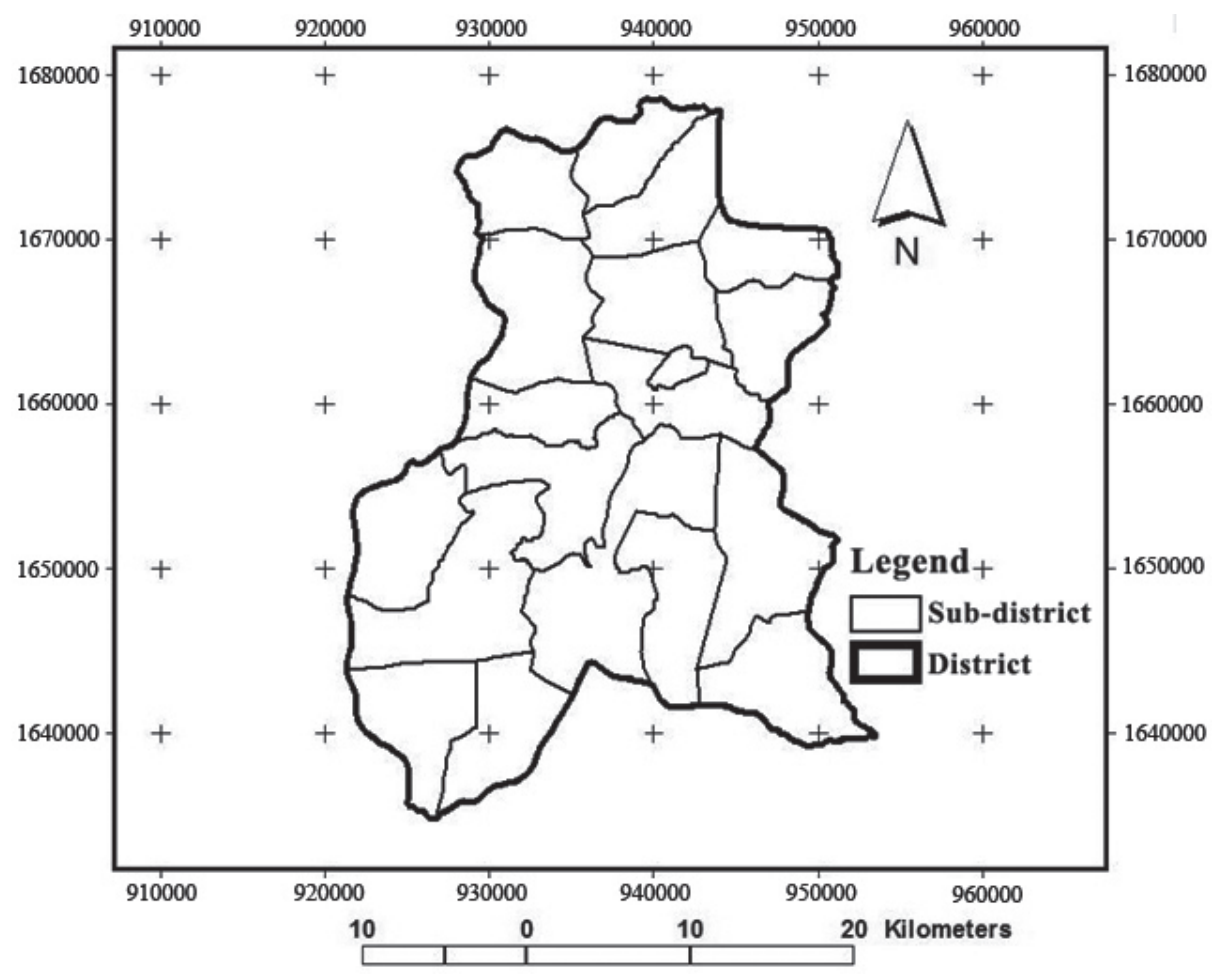

Fig. 1. Mueang Buriram district, Buriram province, Thailand. 
were interested in developing land surface temperature detection methods from space as well. This can be seen from the development of methods to determine land surface temperature such as radiative transfer equation-based method, split window algorithm, singlechannel algorithm, etc. [18-21]. The main objective of this research is: 1) to analysis land surface temperature with Landsat 8 data from thermal infrared wavelength, 2) to analysis urban built-up areas from satellite data from optical wavelength, and 3) to find the relationship between land surface temperature and urban built-up areas.

\section{Study Area and Data}

\section{Study Area}

The study area is Mueang Buriram District, Buriram Province, Thailand, located in the southern part of northeastern Thailand (Fig. 1) between 14'59'42' $\mathrm{N}$ and longitude $103^{\circ} 6^{\prime} 12^{\prime}$ 'E with a total area of $718.24 \mathrm{Km}^{2}$.

\section{Data}

Landsat- 8 satellite data (OLI $30 \times 30 \mathrm{~m}$ and TIRS $100 \times 100 \mathrm{~m}$ sensor systems) recorded path 128 row 50 data in the areas covering Mueang Buriram District, Buriram province from such satellite data recorded on 27 December 2018.

\section{Scope of the Study}

This study is land surface temperature estimation with Landsat- 8 satellite data and thermal infrared sensor (TIRS) in two frequencies including band 10 with a wavelength of $10.6-11.2 \mu \mathrm{m}$ and band 11 with a wavelength of 11.5-12.5 $\mu \mathrm{m}$. Moreover, the splitwindow algorithm was also used to analyze mutually with land surface emissivity and atmospheric water vapor. On the other hand, the Landsat- 8 satellite data in optical wavelength will be analyzed for land use in the study area. However, land surface temperature analysis and land use analysis are performed using mathematical operations combined with digital image processing. In addition, the relationship between land surface temperature and urban built-up areas was analyzed. After that, linear regression equations were created to forecast temperatures in the future.

\section{Operational Method}

This study selected the split-window algorithm to estimate values of land surface temperature by applying thermal infrared sensor data from Landsat- 8 satellites with the steps shown in Fig. 2, which can explain the operations as follows;

\section{The Study of Land Use}

It was a classification process to classify types of data from satellite data using reflection values called digital number for grouping data layers to show physical differences of objects. In this study, supervised classification technique and maximum likelihood classification were selected and used. At any rate, the researcher had classified the data into 3 main groups: 1) vegetation areas, 2) urban built-up areas and 3) water areas.

\section{Brightness Temperature Analysis}

In this study, brightness temperature analyzed global surface temperatures in the thermal infrared sensor radiation phase while the radiance of the object was equal to the radiation of the black body. The radiation of the black body could determine brightness temperature of the object by analysis methods as shown

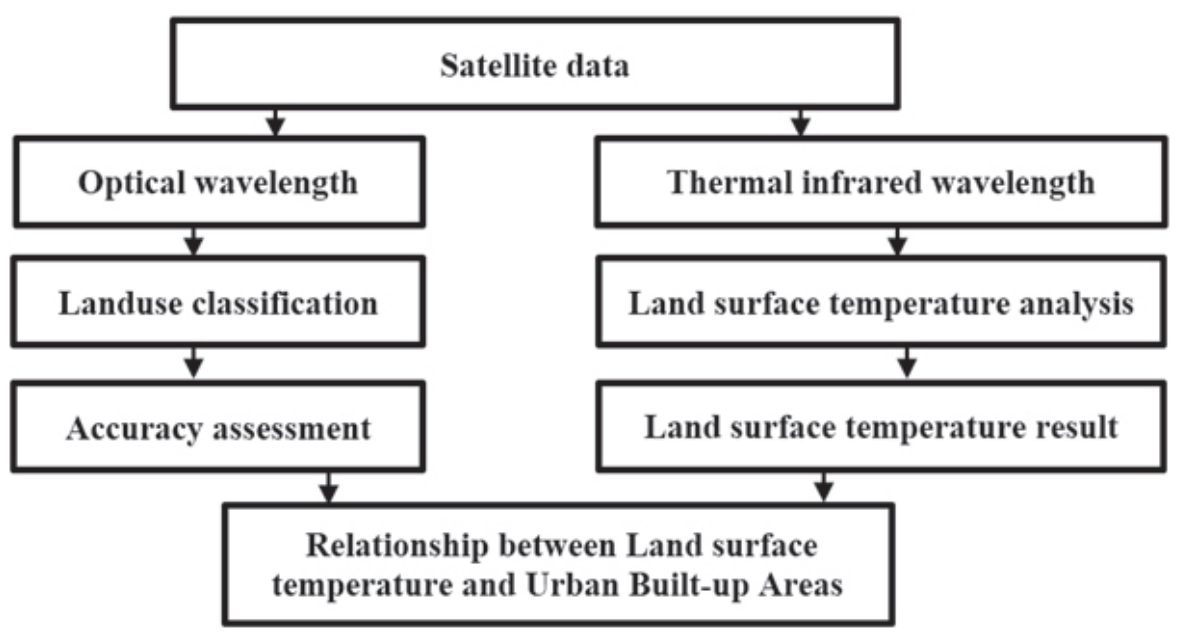

Fig. 2. Flowchart of the study. 
in Equation 1 [22]. Moreover, the radiation of the object depends on the wavelength and the proportion between absorption, reflection, and transmission. The analysis methods are shown in Equation 2 [23]:

$$
T=\frac{k_{2}}{\operatorname{In}\left(\frac{k_{1}}{L_{\lambda}}+1\right)}
$$

...where:

$T=$ Brightness temperature in Kelvin

$k_{1}=$ Constant value of Landsat-8 (b10 $=774.89$ and $\mathrm{b} 11=480.89)$

$k_{2}=$ Constant value of Landsat- $8(\mathrm{~b} 10=1321.08$ and b11 $=1201.14)$

$L_{\lambda}=$ Radiance

$$
L_{\lambda}=M_{L} Q_{c a l}+A_{L}
$$

...where:

$M_{L}=$ Radiance multi band

$A_{L}=$ Radiance add band

$Q_{\text {col }}=$ Digital number (DN)

\section{Land Surface Emissivity Analysis}

Land surface emissivity was an analysis of radiation of real objects on the earth that could not absorb all energy. It was only a small amount of radiation compared to the black body. However, the radiation conditions could be estimated from the proportion of vegetation covering the soil, which could be analyzed from the normalized difference vegetation index (NDVI). The analysis methods are shown in Equation 3 [24].

$$
L S E=\varepsilon_{s}(1-F V C)+\varepsilon_{v}^{*} F V C
$$

...where:

$\varepsilon_{s}=$ Constant value of Landsat- 8 (b10 $=0.971$ and b11 $=0.977)$

$\varepsilon_{v}=$ Constant value of Landsat- 8 (b10 $=0.987 \mathrm{and}$ $\mathrm{b} 11=0.989)$

The analysis of fractional vegetation cover (FVC) was an analysis of the green space cover coefficient, which could be calculated from integrity of vegetation. The analysis methods are shown in Equation 4 [25].

$$
F V C=\frac{N D V I-N D V I_{s}}{N D V I_{v}-N D V I_{s}}
$$

...where:

$N D V I_{v}=$ Maximum value of NDVI

$N D V I_{s}^{v}=$ Minimum value of NDVI
For analysis of the NDVI, it was a calculation for finding out the proportion of vegetation that covers the surface by bringing near infrared wavelengths and red eye waves that reflected from the surface to calculate the difference of reflections. The analysis methods are shown in Equation 5. The $\rho$ was the reflection value of the soil cover. The reflection value depended on the wavelength and the proportion of absorption, reflection, and transmission. The analysis methods are shown in Equation 6 [26]:

$$
N D V I=\frac{\rho_{N I R}-\rho_{\mathrm{Re} d}}{\rho_{N I R}+\rho_{\mathrm{Re} d}}
$$

...where:

$\rho_{N I R}=$ Reflection value of vegetation in near Infrared wave range (NIR)

$\rho_{\text {Red }}=$ Reflection value of vegetation in red wave range (RED)

$\rho=$ Reflection value of the soil cover

$$
\rho_{\lambda}=M_{\rho} Q_{c a l}+A_{\rho}
$$

...where:

$M_{\rho}=$ Reflectance multi-band of Landsat- 8

$A=$ Reflectance add band of Landsat- 8

$Q_{c o l}^{\rho}=$ Digital number (DN)

\section{Atmospheric Water Vapor Analysis}

Atmospheric water vapor could be analyzed from the transmission of electromagnetic wave through the atmosphere with the thermal infrared sensor radiation range using brightness temperature values of b10 and b11. The analysis methods are shown in Equation 7 [27].

$$
W V=a+b \cdot \tau_{j} / \tau_{i}
$$

...where:

$$
\frac{\tau_{j}}{\tau_{i}} \approx R_{j i}=\sum_{k=1}^{N}\left(T_{i, j}-\bar{T}\right)\left(T_{i, j}-\bar{T}\right) / \sum_{k=1}^{N}\left(T_{i, j}-\bar{T}\right)^{2}
$$

...where:

$\mathrm{a}$ and $\mathrm{b}$ are the coefficients of the model $\tau=$ Ability of transmission of electromagnetic wave through atmosphere (b10 and b11)

$i, j=\mathrm{b} 10$ and b11

$T_{i, j}, T_{i, k}=$ Brightness temperature of b10 and b11

$T_{i}, \frac{T_{j}}{T_{j}}=$ Mean brightness temperature of b10 and b11

\section{Land Surface Temperature Analysis}

Land surface temperature analysis in this study analyzed brightness temperature and land surface emissivity values of both wavelengths (b10 and b11) and atmospheric water vapor. The analysis methods are shown in Equation 8 and Table 1 [8]: 
Table 1. Coefficient of the split-window equation.

\begin{tabular}{|c|c|}
\hline Constant & Value \\
\hline C0 & -0.678 \\
\hline C1 & 1.378 \\
\hline C2 & 0.183 \\
\hline C3 & 54.30 \\
\hline C4 & -2.238 \\
\hline C5 & -129.2 \\
\hline C6 & 16.40 \\
\hline
\end{tabular}

$L S T=\left(T_{10}+C_{10}-T_{11}\right)+\left(T_{10}-T_{11}\right)^{2} C_{0}+\left(C_{3}+C_{4} W\right)(1-\varepsilon)+\left(C_{5}+C_{6} W\right) \Delta \varepsilon$

...where:

$T_{10}, T_{11}=$ Brightness temperature of b10 and b11

$\varepsilon=$ Mean LSE of b10 and b11

$\Delta \varepsilon=$ Difference LSE of b10 and b11

$C_{0}-C_{6}=$ Constant value (see in table 2)

$W=$ Atmospheric water vapor (AWV)

\section{Relationship Analysis}

The analysis of the relationship between land surface temperature and urban built-up areas in this study was analyzed at a significance level of 0.01 . The analysis methods are shown in Equation 9:

$$
r=\frac{n \sum X Y-\sum X \sum Y}{\sqrt{\left[n \sum X^{2}-\left(\sum X\right)^{2}\right]\left[n \sum Y^{2}-\left(\sum Y\right)^{2}\right]}}
$$

...where:

$r=$ Pearson's correlation coefficient

$X=$ Percentage of UBA of total area in each district

$Y=$ Average temperature in each district

\section{Creating Linear Regression Equations}

In this study, a linear regression model was created to forecast land surface temperature values in the future. The analysis methods are shown in Equation 10:

Table 2. Land use in Mueang Buriram District, Buriram Province.

\begin{tabular}{|c|c|c|}
\hline Land use & $\mathrm{Km}^{2}$ & $\%$ \\
\hline Vegetation Areas & 118.28 & 14.19 \\
\hline Urban Built-up Areas & 703.40 & 84.41 \\
\hline Water areas & 11.61 & 1.39 \\
\hline
\end{tabular}

$$
Y=a+b(X)
$$

...where:

$Y=$ Land surface temperature from predict

$X=$ percentage of UBA

$a=$ cross point of $\mathrm{Y}$ axis

$b=$ slope

\section{Results and Discussion}

For the results of land use classification by supervised classification and maximum likelihood classification method, it was found that the majority of the areas in Mueang Buriram district had land use in vegetation areas with a total of area of $703.40 \mathrm{~km}^{2}$, equivalent to $84.41 \%$. The majority of the vegetation areas were agricultural areas that grew rice, sugarcane, cassava, rubber tree and so on, followed by urban builtup areas with an area of $118.28 \mathrm{~km}^{2}$, equivalent to $14.19 \%$. Water areas had an area of $11.61 \mathrm{~km}^{2}$, equivalent to $1.39 \%$. In addition, to check accuracy of the land use classification in this study, the researcher had examined the classification by using the Kappa statistics and randomizing 100 sample points from surveying field data in the study area. The sample points of each type of land use had reference points of at least 30 points. At any rate, the results of the study indicated the overall accuracy of $90.70 \%$, which was considered to be at an excellent level. The results of land use classification in this study are shown in Table 2 .

From estimating land surface temperature values with split window algorithm, the results were found that Mueang Buriram district had an average land surface temperature of $29.63^{\circ} \mathrm{C}$, with a highest land surface temperature of $33.27^{\circ} \mathrm{C}$ and a lowest of $28.78^{\circ} \mathrm{C}$. When analyzing the statistics of land surface temperature in each sub-district, we found that Nai Mueang sub-district had the highest average land surface temperature at approximately $33.27^{\circ} \mathrm{C}$, followed by Isan sub-district and Chum het sub-district, with average land surface temperatures of $31.44^{\circ} \mathrm{C}$ and $30.58^{\circ} \mathrm{C}$, respectively (see Table 3). Above all, the sub-district with high average land surface temperature had land uses in forms of urban built-up areas.

For the lowest land surface temperature, the study results indicated that the land uses in these areas appeared to be vegetation areas, including 1) agricultural areas that grew rice, sugarcane, cassava, rubber tree, etc., 2) forest areas located in Lak khet subdistrict, Mueang Fang sub-district, and Nong Tat subdistrict. The land surface temperature values appeared approximately at $28.79^{\circ} \mathrm{C}, 28.85^{\circ} \mathrm{C}$ and $28.87^{\circ} \mathrm{C}$, respectively (see Table 3 ). When comparing land use with average land surface temperature of each subdistrict, we found that the percentage of urban built-up areas per total area of each district were in the same direction as temperatures. This can explain that, when 
Table 3. Land surface temperature with the percentage of urban built-up areas in each sub district.

\begin{tabular}{|c|c|c|c|c|}
\hline Name & Urban built-up areas $\left(\mathrm{Km}^{2}\right)$ & All area of each Sub district $\left(\mathrm{Km}^{2}\right)$ & $\%$ & Land surface temperature Celsius \\
\hline Ban Bua & 07.93 & 51.80 & 15.30 & 29.32 \\
\hline Bua Thong & 03.16 & 27.31 & 11.57 & 29.26 \\
\hline Bua Yang & 05.38 & 33.77 & 15.93 & 29.56 \\
\hline Chum Het & 08.79 & 46.17 & 24.03 & 30.58 \\
\hline Isan & 15.82 & 39.36 & 40.29 & 31.44 \\
\hline Kalantha & 03.20 & 38.93 & 08.21 & 28.97 \\
\hline Krasang & 04.45 & 29.36 & 15.15 & 29.78 \\
\hline Lak Khet & 02.37 & 46.31 & 05.11 & 28.79 \\
\hline Lumpuk & 04.34 & 46.16 & 09.40 & 29.34 \\
\hline Mueang Fang & 02.60 & 40.52 & 06.41 & 28.85 \\
\hline Nai Mueang & 05.35 & 05.48 & 75.62 & 33.27 \\
\hline Nong Tat & 03.96 & 57.61 & 06.87 & 28.87 \\
\hline Phra Khru & 03.05 & 35.81 & 08.51 & 29.46 \\
\hline Samet & 19.58 & 83.70 & 23.39 & 30.46 \\
\hline Sakae Phrong & 08.67 & 74.68 & 11.61 & 28.9 \\
\hline Sakae Sam & 04.92 & 46.89 & 10.49 & 28.98 \\
\hline Sawai Chik & 07.50 & 59.62 & 12.58 & 29.61 \\
\hline Song Hong & 04.47 & 42.99 & 10.39 & 29.32 \\
\hline Thalung Lek & 02.67 & 28.03 & 09.52 & 29.57 \\
\hline
\end{tabular}

the percentage increases, the average land surface temperature of each sub-district will increase in the same way. The districts with high average land surface temperatures (including Nai Mueang sub-district, Isan sub-district and Chum het sub-district) appeared to be due to the increasing percentage of urban built-up areas at $75.62 \%, 40.29 \%$ and $24.03 \%$ respectively. The results of the analysis are shown in Table 3.

An analysis of the results of the relationship between the percentage of urban built-up areas and the average

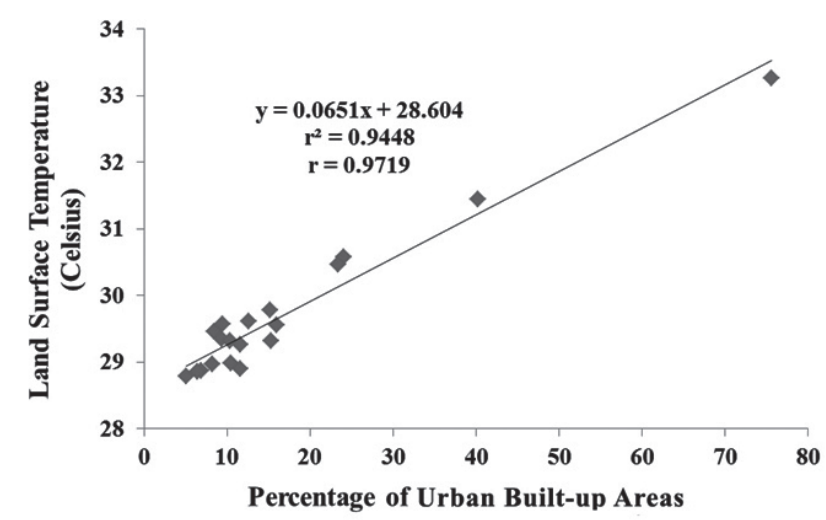

Fig. 3. Relationship between land surface temperature and urban built-up areas. land surface temperature of each district showed that both sets of data were related at a significance level of 0.01 with the correlation coefficient $r$ at 0.9719 . This indicated that both sets of data were highly related in the same direction. Also, it can be additionally explained that when urban built-up areas increase, the average land surface temperature will increase in the same way. Moreover, when such data were brought to create linear regression equations with the method of least squares for estimating off-range values, it was found that the equations obtained had a coefficient of determination $r^{2}$ at 0.9448 as shown in Fig. 3 .

When the data from the equation were brought to forecast the average land surface temperature of the areas in the future, we found that if urban built-up areas of Mueang Buriram district in the future increased to 50, the average land surface temperature of the area was equal to $31.859^{\circ} \mathrm{C}$. When it increased to $60 \%$, the average land surface temperature of the area was equal to $32.510^{\circ} \mathrm{C}$. When it increased to $70 \%$, the average land surface temperature of the area was equal to $33.161^{\circ} \mathrm{C}$. When it increased to $80 \%$, the average land surface temperature of the area was equal to $33.812^{\circ} \mathrm{C}$. When it increased to $90 \%$, the average land surface temperature of the area was equal to $34.463^{\circ} \mathrm{C}$. When it increased to $100 \%$, the average land surface temperature of the area was equal 
Table 4. Proportion of urban built-up areas and land surface temperature.

\begin{tabular}{|c|c|}
\hline Urban built-up areas & Land surface temperature \\
\hline $50 \%$ & $31.85^{\circ} \mathrm{C}$ \\
\hline $60 \%$, & $32.51^{\circ} \mathrm{C}$ \\
\hline $70 \%$, & $33.16^{\circ} \mathrm{C}$ \\
\hline $80 \%$, & $33.81^{\circ} \mathrm{C}$ \\
\hline $90 \%$, & $34.46^{\circ} \mathrm{C}$ \\
\hline $100 \%$, & $35.11^{\circ} \mathrm{C}$ \\
\hline
\end{tabular}

to $35.114^{\circ} \mathrm{C}$. The details of the forecasts are shown in Table 4.

\section{Conclusions}

According to this study of the relationship between land surface temperature and urban built-up areas in Mueang Buriram district, Buriram province, Thailand, the location still has the largest area of vegetation at $84.41 \%$. The majority of vegetation areas are agricultural areas growing rice, sugarcane, cassava and rubber tree and so on, followed by urban built-up areas in a total of $14.19 \%$ and water areas in a total of $1.40 \%$. However, the analysis of the relationship between urban built-up areas and average land surface temperature indicated that such an area had an influence on the increase in the average land surface temperature. The more urban built-up areas expanded, the more the average land surface temperature increased in the same way. From the study of the relationship, the correlation coefficient $\mathrm{r}^{2}$ indicated 0.9448. Moreover, this study had forecasted land surface temperature values in the future and found that when the urban built-up areas were increased up to $100 \%$ of the total area of Mueang Buriram district, the average land surface temperature area of the area was approximately $35.11^{\circ} \mathrm{C}$ and the temperature rose approximately $5.41^{\circ} \mathrm{C}$. In addition, the study results found that the relationship between the percentage of urban built-up areas and the average land surface temperature was positive in the same direction as the research of [28] with the title of "The relationship between land surface temperature and NDVI with remote sensing: application to Shanghai Landsat 7 ETM+ data", [29] with the title of "The relationship between land surface temperature and land use/land cover in Guangzhou, China" and [30] with the title of "Relationship between Land Surface Temperature and Land Use in Nakhon Ratchasima City, Thailand". The results of this study can explain how urban built-up areas tend to expand continually and influence the increase of the average land surface temperature.

\section{Acknowledgements}

This research project is financially supported by Mahasarakham University (Fast Track 2020).

\section{Conflict of Interest}

The authors declare no conflict of interest.

\section{References}

1. LEMKE P., REN J., ALLEY R.B., ALLISON I., CARRASCO J., FLATO G., FUJII Y., KASER G., MOTE P.W., THOMAS R.H., ZHANG, T. Climate Change 2007: The Physical Science Basis. Contribution of Working Group I to the Fourth Assessment Report of the Intergovernmental Panel on Climate Change. Cambridge University Press, Cambridge, United Kingdom and New York, NY, USA, 2007.

2. THAI METEOROLOGICAL DEPARTMENT. Summary of weather conditions in Thailand. Available online: https://www.tmd.go.th/programs\%5Cuploads\%5Cyearly Summary\%5Cannual2558_new2.pdf (accessed on 20 December 2018) [In Thai].

3. DECHAPHONGTHANA W., KARNCHANASUTHAM S., NUALCHAWEE K., INTARAWICHIAN N. Estimation of Land Surface Temperature of Land Using Satellite Data. Thai Science and Technology Journal, 25 (3), 377, 2017.

4. BLACKETT M. Early analysis of Landsat-8 thermal infrared sensor imagery of volcanic activity. Remote Sensing, 6 (3), 2282, 2014.

5. CHEN F., YANG S., YIN K., CHAN P. Challenges to quantitative applications of Landsat observations for the urban thermal environment. Journal of Environmental Sciences, 59, 80, 2017.

6. ASSIRI M.E. Assessing MODIS Land Surface Temperature (LST) Over Jeddah. Polish Journal of Environmental Studies, 26 (4), 1461, 2017. DOI: https://doi. org/10. 15244/pjoes/68960

7. BURIRAM PROVINCE WEBSITE. Buriram province information. Available online: http://www.buriram.go.th/ downloads/summary.pdf (accessed on 30 December 2018) [In Thai].

8. LAOSUWAN T., GOMASATHIT T., ROTJANAKUSOL $\mathrm{T}$. application of remote sensing for temperature monitoring: the technique for land surface temperature analysis. Journal of Ecological Engineering, 18 (3), 53, 2017. DOI: https://doi.org/10.12911/ 22998993/69358

9. WANG F., QIN Z., SONG C., TU L., KARNIELI A., ZHAO S. An Improved Mono-Window Algorithm for Land Surface Temperature Retrieval from Landsat 8 Thermal Infrared Sensor Data. Remote Sens. 7, 4268, 2015.

10. ZHENG H., CHEN Y., PAN W., CAI Y., CHEN Z. Impact of Land Use/Land Cover Changes on the Thermal Environment in Urbanization: A Case Study of the Natural Wetlands Distribution Area in Minjiang River Estuary, China. Polish Journal of Environmental Studies, 28 (4), 3025, 2019. DOI: https://doi.org/10.15244/ pjoes/93743

11. ERMIDA S., DACAMARA C., TRIGO I., PIRES ANA., GHENT D., REMEDIOS J. Modelling directional effects 
on remotely sensed land surface temperature. Remote Sensing of Environment. 190, 56, 2017.

12. ELEFTHERIOU D., KIACHIDIS, K., KALMINTZIS G., KALEA A., BANTASIS C., KOUMADORAKI P., SPATHARA M.E.,TSOLAKI, A., TZAMPAZIDOU M.I., GEMITZI A. Determination of annual and seasonal daytime and nighttime trends of MODIS LST over GreeceClimate change implications. Sci. Total Environ. 616, 2017.

13. DUAN S.B., LI, Z.L., WU H. LENG P., GAO M., WANG C. Radiance-based validation of land surface temperature products derived from Collection 6 MODIS thermal infrared data. Int. J. Appl. Earth Obs. Geoinf. 70, 84, 2018.

14. BOSCHETTI L., ROY D.P., JUSTICE C.O., GIGLIO L. Global assessment of the temporal reporting accuracy and precision of the MODIS burned area product. International Journal of Wildland Fire. 19 (6), 705, 2010.

15. CHAROENTRAKULPEETI W. Impact of Land Cover on Atmospheric Temperature in Bangkok. NIDA Journal of Environmental Management, 8 (1), 1-18, 2012. [In Thai].

16. MALLICK J., KANT Y., BHARATH B. Estimation of land surface temperature over Delhi using Landsat-7 ETM+. Journal of Indian Geophysical Union. 12 (3), 131, 2008.

17. MIRZAEI P.A., HAGHIGHAT F. Approaches to study Urban Heat Island-Abilities and limitations. Building and Environment, 45 (10), 2192, 2010.

18. YU X., GUO X., WU Z. Land Surface Temperature Retrieval from Landsat 8 TIRS-Comparison between Radiative Transfer Equation-Based Method, Split Window Algorithm and Single Channel Method. Remote Sensing, 6 (10), 9829, 2014.

19. REN H., YAN G., CHEN L., LI Z.L. Angular effect of MODIS emissivity products and its application to the splitwindow algorithm. ISPSR J. Photogramm. 66, 498, 2011.

20. DU C., REN H., QIN Q., MENG J., ZHAO S. A Practical Split-Window Algorithm for Estimating Land Surface Temperature from Landsat 8 Data. Remote Sensing. 7 (1), 647, 2015.

21. CHEN F., YANG S., SU Z., HE B. A new single-channel method for estimating land surface temperature based on the image inherent information: The HJ-1B case, ISPRS Journal of Photogrammetry and Remote Sensing, 101, 80, 2015. DOI: https://doi. org/ 10.1016/j.isprsjprs.2014.11.008.
22. ROTJANAKUSOL T., LAOSUWAN T. Estimation of land surface temperature using Landsat satellite data: A case study of Mueang Maha Sarakham District, Maha Sarakham Province, Thailand for the years 2006 and 2015. Scientific Review Engineering and Environmental Sciences, 27 (4), 401, 2018. DOI: 10.22630/PNIKS.2018.27.4.39

23. BARSI J.A., SCHOTT J.R., HOOK S.J., RAQUENON G., MARKHAM B.L., RADOCINSKI R.G. Landsat-8 thermal infrared sensor (TIRS) vicarious radiometric calibration. Remote Sensing, 6 (11), 11607, 2014.

24. RAJESHWARI A., MANI N.D. Estimation of Land Surface Temperature of Dindigul District using Landsat 8 Data. International Journal of Research in Engineering and Technology, 3 (5), 122, 2014.

25. SKOKOVIC D., SOBRINO J.A., JIMENEZ-MUNOZ J.C., SORIA G., JULIEN Y., MATTAR C., CRISTOBAL J. Calibration and Validation of land surface temperature for Landsat8-TIRS sensor. Available online: https:// earth.esa.int/documents/700255/ 2126408/ESA_Lpve Sobrino 2014a.pdf (accessed on 30 December 2018)

26. UTTARUKK Y., LAOSUWAN T. Drought Detection by Application of Remote Sensing Technology and Vegetation Phenology. Journal of Ecological Engineering, 18 (6), 115, 2017. DOI: https://doi.org/10.12911/22998993/76326

27. REN H., DU C., LIU R., QIN Q., YAN G., LI Z-L., MENG J. Atmosphericwater vapor retrieval from Landsat 8 thermal infrared images. J. Geophys. Res.Atmos. 120, 1723, 2015. DOI:10.1002/2014JD022619.

28. YUE W., XU J., TAN W., XU L. The relationship between land surface temperature and NDVI with remote sensing: application to Shanghai Landsat $7 \mathrm{ETM}+$ data, International Journal of Remote Sensing, 28 (15), 3205, 2007. DOI: $10.1080 / 01431160500306906$.

29. SUN Q., WU Z., TAN J. The relationship between land surface temperature and land use/land cover in Guangzhou, China. Environmental Earth Sciences. 65 (6), 1687, 2012.

30. CHOTCHAIWONG P., WIJITKOSUM S. Relationship between Land Surface Temperature and Land Use in Nakhon Ratchasima City, Thailand. Engineering Journal. 23 (4), 1-14, 2019. DOI: https://doi.org/10.4186/ ej.2019.23.4.1 